\title{
Heterodox Political Economy Specialization and Interconnection - Concepts of Contradiction, Heterogeneous Agents, Uneven Development
}

\author{
Phillip Anthony O’Hara*
}

\begin{abstract}
This paper extends the analysis presented by Marc Lavoie in this journal about the relationship between the major schools of heterodox political economy. We argue that the evolution of heterodoxy over the past four decades has seen both specialization and interconnection. The specialization has enabled a degree of detailed analysis of concepts, such as class, demand, institution, innovation, gender, ecology and development. Interconnections between the schools also developed from an early stage. With both forces operating, the specialization promotes clarity of perception and depth of analysis, while the association enables this perception and depth to be linked between the schools. This has led to a degree of cross-fertilisation of themes to form broad concepts. Three such broad concepts are examined that are emerging and link aspects of different schools: contradiction, heterogeneous agents, and uneven development. These broad concepts are important for comprehending the social, institutional and historical forces of political economy, and for linking themes from the various schools of heterodoxy.

JEL classifications: $B 5, J_{I}, O_{I}, P_{I 6}, Z_{I 3}$
\end{abstract}

Keywords: schools of heterodox political economy, specialization, association, concepts, contradiction, heterogeneous agents, uneven development

* Global Political Economy Research Unit (GPERU), Curtin University, Perth. I wish to thank the anonymous referees, editors, Ron Stanfield, and Matthew Wilson for comments and help with an earlier version of this article.

Correspondence Address:

Prof. Phillip Anthony O’Hara, Global Political Economy Research Unit (GPERU), Department of Economics, Curtin University, GPO Box Ui987, Perth, WA. 6845, Australia, e-mail: philoharal@ yahoo.com

Received 14 Aug 2006, accepted 22 Feb 2007

(C) INTERVENTION 4 (I), 2007, 99-I20 


\section{Introduction}

Since the 1960s, especially, heterodox schools of political economy have experienced a considerable resurgence. Much of this was part of the radicalism of the I960s and I970s, and much was a reaction to the narrow formalism of orthodoxy. Whatever the causes, this resurgence has continued to this day. There are many who consider themselves to belong to a specific school or trend, such as institutional, Marxist, feminist, post-Keynesian, Schumpeterian, social, ecological or international political economy. But there are an increasing number who consider themselves simply a heterodox political economist. The latter generally have an eclectic view of the world under the influence of what they consider to be a fairly uniform trend of convergence towards a common science of political economy.

In a recent issue of this journal, Marc Lavoie (2006) has rightly picked up on this theme, providing a post-Keynesian point of view on the question: »Do heterodox theories have anything in common?" He generally answers in the affirmative, paying particular attention to various themes linking some writers of a post-Keynesian, Sraffian and neo-Marxist persuasion. He believes that heterodoxy has many things in common, including shared concepts, but that like all human beings they are likely to disagree on certain things, and that this critique is healthy and wise. However, he denigrates sectarianism, or attempts of some heterodox scholars to shield themselves from other perspectives, engaging in caustic criticism and exclusivity. There is said to be strength in numbers and making positive contributions to heterodox thought.

In exploring this theme, Lavoie delimits the scope of his analysis to four themes: the concept of rationality, price theory, growth theory and links between money and production. First, much emphasis was given to the heterodox tendency to utilise bounded (or substantive) rationality, since asymmetric information, uncertainty, interdependent choices and adjustments are critical to the human predicament. Second, he examines pricing theories in the short and long run, and argues that in the short-run cost-plus pricing procedures are acceptable to all, adjustments are made through quantities, and are sticky; while in the long-run we can concentrate on the gravitation problem, or the convergence towards prices of production. Third, he discusses the relevance of the Kaleckian model of growth, which is driven by effective demand. Here demand creates its own productive capacity, and one can differentiate between the current period and long-run utilisation rate. Lavoie emphasises relationships between Sraffians, Kaleckians, and certain neo-Marxist scholars and links class conflict with economic activity. Lastly, he discusses the considerable similarities among heterodox scholars in understanding growth and (un)employment within the context of a monetary theory of production. Extensions have been included for open-economy considerations.

Lavoie discusses these four themes within the context of recent trends and relationships between heterodox scholars, which he believes are consistent with a more eclectic and open-minded spirit. Such a spirit is certainty at play. Consider, for instance, the fact that recently, two Marxist-institutionalists (Paul M. Sweezy and Howard Sherman) and 
three radical-institutionalists (Bill Dugger, Dan Fusfeld and Ron Stanfield) have been awarded the Veblen-Commons Award from the Association for Evolutionary Economics (AFEE). Also, the formerly more Marxist Review of Radical Political Economics editorial policy now

"publishes innovative research in political economy broadly defined as including, but not confined to, Marxian economics, post-Keynesian economics, Sraffian economics, feminist economics, and radical institutional economics« (RRPE 2006).

Also, several broad-church political economy journals now exist, including the Review of Political Economy which

"welcomes constructive and critical contributions in all areas of political economy, including the Post-Keynesian, Sraffian, Marxian, Austrian and Institutionalist traditions« (RoPE 2006). ${ }^{1}$

Similar sorts of linkages and associations are also typical of other journals, such as New Political Economy, the Cambridge Journal of Economics, as well as at conferences of heterodox scholars in many parts of the world.

The purpose of this paper is to continue the debate concerning the theoretical linkages between the various traditions of heterodoxy. Lavoie emphasised that his paper was only partial and selected only a few areas of analysis. Indeed, it was one post-Keynesian view on these matters. This current paper starts off by looking at the main differences and specializations associated with the schools of heterodoxy. It is argued that these differences have been critical to the theoretical corpus of political economy. Specificity of focus is necessary before and during the process of interconnection and association. The very differences between the schools have become a source of multiple innovations as cross-fertilization generates richer research programs and broader concepts. With such a multitude of theories and perspectives, due to both specialization and interconnection, it is now possible to develop broader foundations for the science of political economy.

After the main differences and specializations are examined, the paper examines three »broad« concepts of emerging significance

"that include reflections on the historical and social factors that shape economic processes, and that explicitly explore opportunities for human action to actively intervene and shape economic policies« (IJE 2006).

Broad concepts have been emerging from specialization and interconnection between the various schools which enhances heterodoxy. Three such concepts, which have been in

I The various elements of the Austrian School represent an especially difficult question for heterodox political economy, since on the one hand they are heterodox vis-à-vis their emphasis on uncertainty, institutions, and evolution, on the other hand they are more orthodox in relation to spontaneous market processes, liberty and the role of the individual. To include them in this paper would have unduly complicated the process and reduced the degree of continuity of the schools. 
the process of enrichment to varying degrees, include (a) contradiction, (b) heterogeneous agents, and (c) uneven development. These concepts are much broader in scope than those analysed by Lavoie and place more emphasis on the institutional and historical underpinnings of socioeconomies.

\section{Differences and Linkages between the Schools of Heterodoxy}

Heterodox scholars have tended to assume that differences among and between the schools of thought are inconsistent with the process of convergence, linkage and commonality. I argue the opposite, namely, that differences are essential to a vibrant and forwardlooking science and enable innovations and new research programs to be made through linkage and communication. There are often time lags between greater specialization or technical development and the development of large concepts that link various schools of heterodoxy. But over time major advances are possible through cross-fertilization and assimilation.

Some large measure of specialization has been happening in political economy over the past forty years (at least). Each of the major schools of thought has concentrated on the core theories of their analysis, and has gained a conspicuous place in the theoretical edifice of academia. Without this degree of specialization little progress would have been made in political economy. This section outlines the broad nature of the specializations, and then shows how advances have been made by linking advances of the various schools. Further sections detail three of the broad conceptual developments that are emerging in an evolutionary fashion.

Marxists have specialised in class analysis and the production of an economic surplus through the circuit of social capital. Various forms of Marxism have generated quite different analyses of these matters: rational choice Marxists, Rethinking Marxists, and so on. But this has typically been their main substantive research program for comprehending the dynamics of capitalism. Stephen Resnick and Richard Wolff (2005) have, for instance, directed their attention in this respect to the differences between fundamental class processes, associated with productive workers and industrial capitalists producing the surplus; and subsumed class processes, linked to the distribution of the fruits of surplus labor; as well as the institutional conditions of existence of non-class processes. Much Marxian economics, including criticism and reconstruction, has been published in journals such as the Review of Radical Political Economics, Capital and Class, and Rethinking Marxism. Some of the key books include Resnick and Wolff (1987) Knowledge and Class, Howard Sherman (1995) Reinventing Marxism, and John Milios et al. (2002) Karl Marx and the Classics.

Post-Keynesians have similarly specialised in economic discourse with the aim of developing an original and compelling conceptual framework of the workings of capitalism. The main corpus of this framework has been the principles of effective demand and uncertainty. Generally, effective demand is seen as part of a circular and cumulative process, 
wherein demand itself is able to generate expansions of supply through learning by doing, economies of scale/scope and innovation. The dynamics of capitalism tend to be unstable through business cycle type fluctuations. A critical source of this instability lies in the process of uncertainty. Because investment is generally undertaken with a view to the future, when economic conditions are unknown, uncertainty is the critical foundation of capitalism. Conventions are used to reduce uncertainty, including accounting techniques, corporate planning, and trying to follow the market. The prevailing business climate becomes the main determinant of investment. Post-Keynesians have developed numerous theories and approaches to this subject, including substantial internal criticism, especially in the Journal of Post Keynesian Economics and the Cambridge Journal of Economics. Some key books include Marc Lavoie (1992) Foundations of Post-Keynesian Economic Analysis, Douglas Vickers (1995) The Tyranny of the Market, and John King (2002) A History of Post Keynesian Economics Since 1936.

Institutionalists, meanwhile, have been busy over the past four decades developing their own theories and approaches. Like the other schools an array of different and often competing approaches were experimented with. Looking at the field from afar, after forty years, we can now see that the essence of the program concerns the relationship between institutions, habits and instincts. Institutions are those durable relationships that condition social behaviour, including structural institutions such as the state, corporation and family, as well as the ideological and normative ones of thought and behaviour. Habits are individual modes of behaviour that stimulate regularity and patterned behaviour. Instincts are the broad, biologically driven, propensities which are capable of varying patterns of manifestation; such as the parental, workmanship, and idle curiosity instincts. The relationship between institutions, habits and instincts is critical as it shows how the biological, individual and social realms link to the creation of human social economy. The work of institutionalists has surfaced especially in the Journal of Economic Issues since 1967 , and much more recently in the Journal of Institutional Economics. Core books are Ron Stanfield (1995) Economics, Power and Culture, Marc Tool (200I) The Discretionary Economy, and Geoffrey Hodgson (2004) The Evolution of Institutional Economics.

Since the late 1960s, neo-Schumpeterian themes have re-emerged, with an emphasis on innovation, creative destruction and diffusion of the technological advances of capitalism. Major advances have been made concerning new products, processes, sources of raw material, new markets and changes in industrial organisation. The Schumpeterianevolutionary trend centres on the direct source of profit and the ongoing dialectic of innovation $\rightarrow$ profit $\rightarrow$ competition necessary for continual advancement. They also recognised the unstable motion of capitalism through long waves and cycles, and the role of credit in the process of development and instability. Contributions were also made concerning the non-class role of entrepreneurs as radical individuals upsetting established institutions of business, and also corporations establishing research and development activities along institutional lines. Much of their work has been published since the late 1980s and early 1990 in the Journal of Evolutionary Economics and Structural Change and Economic Dynamics. Key monographs are Clark and Juma (1987) Long-Run Economics, Brian 
Arthur (1994) Increasing Returns and Path Dependency in the Economy, plus Freeman and Louca (2002) As Time Goes By.

Development and international political economy has perhaps been the most successful area of heterodoxy. Here the "traditional « heterodox concerns of history, institutions, and long-term change could be linked to factors contributing and hindering progress, along with the forces propelling the uneven and unstable performance of neoliberal capitalism. This diverse field emerged in the I950s, became radicalised in the r960s, declined somewhat in the I970s, took a conservative turn in the I980s, and since then has blossomed in the I990s and 2000 s along numerous lines. Development political economy has advanced along with the work of Amartya Sen and Paul Streeton while international political economy has come to the fore in recognising the multifarious forms of organisation and dynamics of global capitalism. Both have been taking an interdisciplinary approach and expanding while comprehending the social, political and institutional forces operating on the global economy. Major innovations have been published, for instance, in World Development, the Review of International Political Economy, and more latterly the Journal of Human Development. Influential books in the field include Robert Keohane (1984) After Hegemony, Amartya Sen (1999) Development as Freedom, and Peter Dicken (2003) Global Shift.

The past forty years has also seen the evolution and development of feminist political economy. The re-emergence of feminism in the 1960 set in motion a whole array of academic works in all major fields of the social sciences concerning gender. In political economy, close links were established between feminists, Marxists and institutionalists. In recent years, feminists have formalised the establishment of the International Association for Feminist Economics (IAFFE) and also Feminist Economics. Major developments have occurred in three major fields: gender relations have been incorporated into economic analysis; linkages between gender, class and ethnicity have been forged in theory and practice; and, more generally, a holistic and processual perspective has been developed on the social economy. Major developments have occurred, and debates on these themes have evolved in all areas of economics. Heterodox perspectives are arguably the dominant discourse in the field as the notions of gender, class and ethnicity challenge more orthodox perspectives of the economy. Core books include Joyce Jacobsen (1994) The Economics of Gender, Gillian Hewitson (1999) Feminist Economics, and Jaquette and Summerfield (2006) Women and Gender Equity.

With the deteriorating global environment, ecological political economy has expanded over the past few decades as a transdisciplinary analysis of ecological capital, strong sustainability and the precautionary principal. This has led to the emergence of many new journals and associations, including the International Association for Ecological Economics (and its regional affiliations), their journal Ecological Economics, and a whole host of others such as Capitalism, Nature and Socialism, the International Journal for Environmental and Sustainable Development, and Environment, Development and Sustainability. In the light of the growth of durable fixed capital, automobile use and extensive logging of old growth forests, the quality of the environment has declined, leading to global warming 
and climate change. In this context, a host of socioeconomic indicators have been emerging, such as the Index of Sustainable Economic Welfare (ISEW), the Genuine Progress Index (GPI) and the Index of Community, Warranted Knowledge and Participation (ICWP). Important books in the field are Nicholas Georgescu-Roegen (197I) The Entropy Law and the Economic Process, Daly and Cobb (1989) For the Common Good, and Robert Costanza (ed.) (I99I) Ecological Economics.

In the light of this activity of the schools over the past forty years, a multitude of evolutionary forces have been operating. These evolutionary forces have variously been promoting differences between schools, similarities between some schools, and a whole host of other changes, including an impact on orthodoxy. Concerning differences between the schools, the primary impact is that some degree of specialization has become possible, building on earlier work, and progressing further. This specialization has enabled conceptual development which otherwise likely would not have occurred. Some scholars have been eschewing linkages, often fighting for a special place for their school, so that conceptual development can occur. Such developments have been considerable in class analysis and the economic surplus; effective demand and uncertainty; institutions-habits-instincts; innovation-profit-competition; uneven development, capabilities and social capital; gender, class and ethnicity; uneven development, hegemonic dominance and production networks; and strong sustainability, precautionary principal and ecological capital. Major debates, alternative views, and many criticisms have blossomed in the various fields. The schools of thought have established themselves on firm ground.

Even while the schools have been developing/enhancing their own perspectives and concepts, many scholars started using concepts linked with other schools to promote their own explanations for the socioeconomic problems of capitalism, and in order to comprehend institutional changes that have occurred. Neo-Marxists in the ro7os and I980s started to incorporate institutional theories of change and crisis that drew heavily if unwittingly on the academic turf of institutionalists. These include regulationists and social structure of accumulation scholars. Marxists and feminists worked together (often critically) to develop an understanding of household labor, segmented labor markets and the nexus between class, gender and ethnicity. Post-Keynesians and Sraffians recognised the potential continuity between short and long run processes. Schumpeterians and postKeynesians began to see how innovation and effective demand are related in a circular and cumulative framework. Marxists and feminists began to appreciate the significance of ecology and the environment for their own view of the limits of capitalism. Development and international political economists drew widely from apparently disparate sources to promote their holistic view of uneven development. Feminists and institutionalists worked together to develop a Veblenian analysis of gender, conspicuous consumption and ceremonial encapsulation.

Specialization has enabled the promotion and development of concepts, which led to the possibility of linkages between traditions, and thereby to the enrichment of theory and practice. As knowledge grows, and problems emerge in the economy, scholars are able to develop a more holistic vision, and thereby recognise how apparently different 
aspects are related. Thus, while we still have different schools, and further specialization, there is now such a tremendous degree of interconnection, communication and correspondence between previously different traditions that a whole range of research programs are emerging from heterodoxy. Indeed, much of this has impacted on orthodoxy, and some Nobel Prizes have been awarded where heterodox ideas have been linked to established ways of looking at the world. ${ }^{2}$

Hence, differences have become a source of communication, innovation and convergence. Differences remain, necessarily since they are critical to further development as well as enrichment. But as heterodox scholars gain a wider view of how capitalism changes and evolves, they often utilise concepts and tools of other scholars to enhance their own perspectives. This is a reason why political economists of originally differing perceptions have been engaging in cross-fertilisation of ideas at conferences, in journals and in academic departments. This has especially been the case through the various international associations of heterodox economics, including the meetings of the various groups at the Allied Social Sciences Association meetings in January of each year in the US; the meetings of the International Confederation of Associations for Pluralism in Economics (ICAPE); the European Association for Evolutionary Political Economy conference in November of each year; and of course in the broad-church journals such as the Journal of Economic Issues, Cambridge Journal of Economics, Review of Political Economy, New Political Economy, Journal of Human Development, and the Intervention. Journal of Economics. Some of the core books illustrating this linkage between schools include Howard Sherman (1987) Foundations of Radical Political Economy, Charles Whalen (1996) Political Economy for the 2It Century, and Phillip O'Hara (2000) Marx, Veblen and Contemporary Institutional Political Economy.

It is thus necessary for heterodox scholars to engage in a multitude of research programs, some of which are specialist areas and some of which cross-fertilise with other traditions. It is imperative to have differences between the schools, as often this represents more specialist knowledge that can later be used in a wider context. If only convergence (without specialization) occurred this would inhibit the further development of heterodoxy into the future. A multitude of patterns and processes, incorporating innovations, experiments and cross-fertilizations are required after a degree of specialization has occurred. Now that some necessarily somewhat narrow level of expertise has ensured, the coevolution of further specialization and cross-linkage can advance political economy further.

In the sections that follow, I provide examples of conceptual developments in heterodoxy that emerged out of the different works of the various schools. These examples are broad ranging, and enable greater holistic vision for political economy as a whole. Had the different schools not specialised then the broader innovations discussed likely would not have been possible. On the other hand, eventually linkages and communications are

2 Here, of course, we are alluding to the awarding of the Nobel Prize to Douglas North, for his contributions to institutions and economic history; and Amartya Sen for his analysis of capabilities in development. 
necessary for the innovations to be recognised and incorporated into heterodoxy. Three examples of such broad concepts that are continually evolving are discussed in subsequent sections: the concept of contradiction; the concept of heterogeneous agents; and the concept of uneven development. ${ }^{3}$

\section{Concept of Contradiction}

Works combining the insights of Marxist, institutional, post-Keynesian, Schumpeterian, feminist, development, ecological and social political economists are able to generate the evolution of a very broad concept of endogenous contradictory processes. This concept of contradiction is necessarily broad because it links similar types of processes examined by members of different schools. The general notion of contradiction is that there are endogenous, open-systems anomalies linking positive and negative forces of a system, which periodically lead to problems of socioeconomic reproduction. Now that the schools have suitably examined in some detail their own view of the contradictions, it is possible to recognise the connections between them and posit a general concept for heterodoxy. ${ }^{4}$

Various dimensions to the notion of contradiction have been provided. For instance, at the very general level, Polanyians, Schumpeterians and others have persistently developed the related contradictions of the disembedded economy and creative destruction. Marxists have posited contradictory processes at work between capital and labor. Marxists, post-Keynesians and institutionalists have detailed the contradictions between industry and finance. Feminists have written extensively about the contradictory relationships underlying gender, ethnicity and class. Environmentalists have elaborated on the contradictions emanating between profit and the environment. And institutionalists and radical political economists have recognised the contradictions operating within and between institutions.

Overall, the concept of contradiction states that there are positive and negative features of socioeconomic systems that are endogenously ingrained in the fabric of various processes, institutions and relationships. These positive and negative elements are fused together in the structure of the system, and help promote dynamics and change. Usually, though, the system cannot abstract from the positive and negative elements because they are both essential to its functioning (to varying degrees). Sometimes the positives outweigh the negatives and sometimes the opposite prevails, depending on the state of the system. The most general system contradiction of capitalism is the Polanyian notion of the dis-

3 For alternative (though complementary) visions of these themes which are more comprehensive see O'Hara (2007b).

4 The notion of contradiction has a long and varied history in political economy and philosophy. Hegel developed it in the most refined way, and then Marx utilised it to examine system-problems. Thereafter, Veblen, Schumpeter and Keynes examined various dimensions to these complex problems. For further reading, see O'Hara (200I, 2006a and 2006b). 
embedded economy (Polanyi 1944). It states that the free market system tends towards instability if left to itself, and thereby requires the injection of fresh forms of reciprocity, redistribution and informal marketplace changes to create system functions. Social and political relationships are, therefore, required to solve the major contradictions of the day that emanate from the concrete workings of the institutions, human interactions and environmental processes. ${ }^{5}$

Under this umbrella are a series of more specific contradictions. A primary one relates to the conflicting workings of the capital-labor relationship, whereby neo-Marxists and radical political economists, especially, have made contributions. Changes in this relationship engender potential positive and negative elements. For instance, a series of major technological changes associated with globalisation, telecommunications and biotechnology can lead to the sneed for greater mobility of capital and labor; the development of new skills and aptitudes; as well as changes to the systems of industrial relations. Such changes may well be time consuming, uneven, and imposing substantial costs on labor and firms. Some scholars may only see the positive things, such as greater innovation, competition and efficiency (Schumpeterians); while others may only see the negatives, including a breakdown in community relations, inequality and anomalies of adjustment and change (sociologists). They are, however, merely both sides of the same coin, and a thorough appraisal of the nature of the changes may require quite different measures of socioeconomic performance (Ghosh/Guven [ed.] 2006). ${ }^{6}$

A further contradiction is that between finance and industry, an area that naturally links Marxists, post-Keynesians and institutionalists. Capitalism requires that financial institutions be balanced by the requirements of promoting industry and innovation. Finance should serve the interests of industry in terms of promoting workmanship, productivity and output. When finance performs that function well the system will, other things being equal, perform well. However, capitalism tends periodically either for finance to dominate industry (mostly), or in some cases, for industry to dominate finance. The postwar (1945-73) system of advanced capitalism, for instance, established a system where finance and industry were in relative balance, through a series of financial regulations and industrial innovations such as the suburban system of household durables and automobile infrastructure of roads and highways. When this system failed, partly due to maturation of systems of innovation, the existing system of regulated finance was said to be at fault, and so deregulation was instituted into the late 1970s, I980s and early I990s globally.

$5 \quad$ For further detail about the disembedded economy, originally developed by Karl Polanyi, see especially the work of James Ronald Stanfield (1986). The relationship between Polanyi's work and that of social and cultural capital discussed later in this paper, is very obvious.

6 For instance, in order to gain a more complex view of the contradictory processes, it is likely to be necessary to not only gain a thorough historico-institutional overview of political economies, but also likely necessary to investigate an array of different measures of performance and welfare. This could include, for instance, apart from the narrow formulations of gross domestic product (and world income) others such as the Human Development Index (HDI), the Gender Empowerment Index (GEI), the Index of Community, Warranted Knowledge and Participation (ICWP). 
As the free market system became more dominant, so finance capital began to dominate industry into the 1980s and I990s (as it had in the I920s and early 1930s) (Stockhammer 2004). This contributed to a series of major speculative bubbles, financial crises and deep recessions in Asia, Latin America, Europe and the US in the late I990s and early 2000 . Out of this emerged a movement for a Post-Washington consensus where finance is again being tied more closely to the interests of industry and system-function of stability.

One of heterodoxy's core concerns is the contradiction between individual and society. In this, human beings are seen as essentially social beings, in need of sociality and interaction for the development of person. One of the great revolutionary aspects of capitalism is that it establishes social value and transcends local, state and national boundaries in the pursuit of global accumulation and growth. Capitalism thus eschewed »rural idiocy« in the pursuit of worldly concerns. This is a positive aspect of the system. But, on the other hand, in establishing such a revolutionary system it poses continual risk of social dislocation. Under neoliberal globalization, the world market is developed as local community networks typically break down. As commodity relationships expand so household activities deteriorate. As the rule of capital establishes a power base so worker involvement in decision-making is eschewed. Free market capitalism is thus a gluttonous system dependent upon continual transformation and disarray, wrecking social interactions of friendship and family, and destroying life outside of markets and corporations (Stanfield 1995). ${ }^{7}$

Global atmospheric concentrations of carbon dioxide have expanded progressively, especially through the 1980s, I990s and 2000s, and global warming has become a serious concern. The contradiction between environmental protection and durable fixed capital is thus a critical problem as the public goods of a relatively clean environment, species survival and relative climate stability have deteriorated in the pro-business global economy. Greenhouse gasses are likely to get worse, global warming to expand, species habitat and biodiversity to decline even further. A major problem is the ideology of weak sustainability, where it is acceptable to trade off lower levels of ecological capital for higher levels of durable physical capital. This leads in the long-run to lower levels of well-being as the declining stock of ecological capital leads to fewer species, more overcrowding, greater levels of stress and inferior quality of life (Brown 2002). The long-term viability of ecological capital thus requires to some degree that we transcend deregulated markets towards a post-neoliberal form of governance; and that we support the notion of strong sustainability, where critical forms of natural capital cannot be sustainably traded off for greater durable fixed capital.

This section has examined various contradictory processes and thematic linkages. The general theme links to the disembedded economy which is closely related to creative

7 A commodity- and capital-driven system thus leads periodically to a breakdown in social relationships at work, throughout the community and in the household. Lacking democracy in the workplace leads to alienation of workers from their product, from their fellow workers and also from themselves as social beings. Exploitation in the workplace can itself negatively impact on productivity and profit as it creates conflictual elements between classes. Increasing commodification can destroy elements of civil society. 
destruction, while the more specific ones concern capital and labor, finance and industry, individual and society, and profit and environment. Others could be incorporated in the analysis, but this overview should suffice for our purposes (see O'Hara 2006a). Various schools of heterodoxy specialise in these various contradictory processes, and it is through a combination of specialization, communication and convergence that the broader linkages can be understood more readily.

\section{Concept of Heterogeneous Agents}

Political economists have always been concerned with the role of groups and classes of people, since they believe the asymmetrical distribution of income, wealth and power creates divisions between people. These differences are critical to contemporary political economy because they provide a degree of realism, and contribute to the linking of individuals and society to solve that age-old problem of voluntarism versus structure. The differences we are primarily concerned with here link to species, class, gender, and ethnicity. ${ }^{8}$

A primary differencer is based on species. Veblen, in particular, centered his analysis, notably in The Theory of the Leisure Class (1899), on active human beings operating in an ecological and social environment, with certain instincts and characteristics that make them both similar and different to other species. Human beings have a gene pool and social systems that influence their characteristics and behavior. Instincts, for Veblen, became part of the systemic processes affecting and in turn being affected by the institutional setup of societies because they are important to human beings as species and social beings. As environmentalists, especially, have recognised, human beings have more power than other species, and therefore are unlikely to protect the environment beyond a minimum level, and therefore major initiatives are likely necessary for sustainable development into the future.

Marxists originally linked their class analysis of capitalism to a simple model of workers and capitalists. Over time this became more sophisticated through the recognition of further layers of workers as well as capitalists, on the basis of occupations, roles, and institutions. Then in the 1960s onwards radical political economy created the segmentation labor market theory. Special reference was given to primary, secondary and tertiary tier workers, depending on their income, occupational power and social position. >People of color and women tend to be overrepresented in the lower segments of the labor market; while white, male workers are over-represented in the middle and upper reaches where higher income and internal ladders led to easier promotion, income and power.

8 While these are the primary heterogeneous agents from a heterodox point of view, the analysis of such heterogeneous agents can be extended to include other dichotomous relationships. These may include lenders and borrowers, buyers and sellers, renters and rentiers, money capitalists and industrial capitalists, teachers and students, and so on. A couple of paragraphs in this section depend on O'Hara (2007a). 
Gender also impinges on the unequal distribution of resources, as feminists and radical political economists have especially recognised. Historically, the gender one is born into has influenced the power one has in different spheres of socioeconomic life. Throughout much of history - still in many nations - women have looked after the family in the private sphere while men worked in the public sphere of life. This asymmetric distribution of social power usually gave men the capability of determining the nature of the institutions of production, distribution and exchange as well as the shape of the spheres of politics and the world economy. Women may have had some power in the household, but little control over social resources, economic and political power and the shape of the world. In the West, especially, women have been questioning this patriarchal dominance, and some redistribution of income, wealth and power has occurred over the past forty years in particular. But substantial power differentials still exist, even in the Western world, that continue to impinge on gender access to resources and quality of life. For instance, in heterosexual relationships, women tend to perform a double day, where they work for wages and then do most of the household labor as well, which negatively affects their levels of wealth and well-being (MacDonald et al. 2005).

Ethnicity is also important. Being brought up in a disadvantageous minority group tends to inhibit the ability of people to realize their potential in areas such as occupation, income and networks. Such minorities tend to have a higher than average incidence of crime and incarceration, lower educational opportunities, plus smaller income and wealth. In general, their life chances are inhibited due to factors beyond their control. For instance, being part of an indigenous population is usually a handicap, since not only one's parents but also other relatives, friends and neighbors have a comparatively lower ability to participate in the economic, political and social affairs of a region, nation and world. When a neighbor or friend becomes more successful they usually move to a "better" suburb or area, thus reducing the extent to which they can function as a role model for others (Darity et al. 200I). The negative affects of lower socioeconomic membership on health and well-being are well known and have been documented extensively in the literature (e.g., see Drentea/Goldner 2006).

For instance, inequality in the US has progressively increased through the 1980 os and I990s. Class distinctions have expanded as the ability of middle and upper class parents to pass socioeconomic advantages on to their children has increased while that of working and lower classes has diminished. The measure of intergenerational elasticity of family income on son's earnings increased from 0.217 (1980) to 0.414 (1993). However,

"nearly all of the increase in the intergenerational elasticity [...] of income operates outside of the [human capital] channels that have been traditionally studied by economists« (Levine/Mazumber 2002: 25).

Bowles and Gintis (2002: 17), for instance, demonstrate that the major factors promoting intergenerational transfers over time are, in order of importance, (a) environmental factors within families and groups (correlation of o.2), (b) wealth of families and groups (o.I2) and genetics (0.09), giving an overall correlation of $0.4 \mathrm{I}$. 
The environmental influences have been studied by a number of authors, such as Annette Lareau (2002: 772) who argues that

"class position influences critical aspects of family life: time use, language use, and kin ties. [...] [P] arents do transmit advantages to their children in patterns that are sufficiently consistent and identifiable to be described as a >cultural logic of childrearing".

Middle class parents tend to have the cultural logic of "concerted cultivation «, where they actively foster and assess the talents, opinions and skills of their children; organize multiple leisure activities; give reasoned directives while allowing contestation and negotiation in decision-making; have weak extended family ties, but more links to the wider community; and encourage a sense of entitlement among children. Working class and poor parents, on the other hand, tend to concentrate on "natural growth " with less guidance; providing directives to children without contestation; and contributing a source of constraint on child development.

A similar empirical assessment is provided by Carl Bankston and Min Zhou (2002), who conclude that the role of intergenerational networks is critical to class and ethnic advantages. They demonstrate that the network ties among parents, children, and friends are significantly weaker among lower classes, Blacks, Asians, and Latinos than middle and upper classes and Whites. Family income and education is positively associated with network ties, especially through the role of the high status, working mother who generally has an active role to play in these networks. Single parents and non-working mothers have significantly less impact than couples and working mothers. Thus,

"[r]esidential stability, knowing the neighbors, parental membership in organizations, and children's involvement in [...] institutions are all positively associated with connections among parents and children. [...] Family income is positively associated with educational aspirations, but negatively related to an orientation to industriousness« (Bankston/Zhou 2002: 30I, 304).

Heterodoxy has thus made significant advances in comprehending the role of different groups and relationships in the social economy. Many of the schools have concentrated on specific aspects of these differences. Once the detail has been provided, though, it is possible to fuse various elements to gain a conceptually integrating perspective on heterogeneous agents. Further knowledge and expertise is required on both the specific groups as well as the more general concepts. Much work awaits us in the future in this critical, broad area of political economy.

\section{Concept of Uneven Development}

Heterodox political economy has contributed more than anything else to questions of development, according to a content analysis of the persons included in A Biographical 
Dictionary of Dissenting Economists (Arestis/Sawyer [eds.] 200o). This is true not only in relation to persons involved directly in sdevelopment issuesı, but also when one recognises that most of the great political economists placed a great deal of emphasis on idevelopment and long-term change (O'Hara 2003: I4I-I42).

Out of all this activity emerges a challenge to orthodox concepts such as global convergence. The alternative concept of uneven development, which has a long history in political economy, is linked to a number of factors, which recognise that there are limits to the extent that nations, regions and localities are able to advance to higher levels of existence, with a sharp limit on the catching-up process. Two sub-concepts will be emphasised here: the terms of trade and social capital. A critical factor is the global division of labor and the trade system. Unequal power relations are influenced in part by the terms of trade, a theme developed especially by post-Keynesian and structuralist political economists. A critical problem has been the tendency for the terms of trade to decline for primary products such as agricultural goods, metals, mining and even low-value added manufactures. This problem, called the Prebisch-Singer hypothesis, has been found to be inhibiting the growth and development of especially sub-Saharan Africa, Latin America and parts of South Asia. David Sapsford and V.N. Balasubramanayam (2003), for instance, argue that both trend and volatility are significant in the terms of trade. Over the twentieth century, relative primary product prices (compared to manufactured goods) have declined by about forty percent, while the cyclical instability problem has become very significant. Some authors concentrate on trend while others emphasise structural breaks. Either way, the periods of major decline and instability have been during long wave downswings the 1920s-30s and 1970s-1980s (see Cuddington et al. 2002).

Over the Ioo years from the early I900s to the early 2000s, price instabilities have beset most commodity prices, with declines being especially marked for copper, jute, maize, aluminium, cocoa, cotton, tea, silver, wool, hides, lead, rice, sugar, and wheat. Substantial price increases were characteristic of lamb, timber, tobacco, beef, coffee and petroleum. Typically, "tropical " agricultural products declined considerably while "non-tropical« did not (Ocampo/Parra 2004). Overall, the commodity terms of trade $-P p / M p$, the index of primary product prices divided by manufactured goods prices - has declined significantly over the period. As a result, the net barter terms of trade $-X p / M p$, the index of export prices divided by import prices - declined in average annual growth terms by 0.50 percent for the poorest nations of the world; there was zero growth for medium income nations; and annual average growth for high income nations was 0.23 percent (Lutz 1999: 862). Critical problems are the relatively low world income elasticity of demand for primary products, the introduction of alternative synthetic fibres in the North, and the static view of comparative advantage that reinforces the reproduction of relatively unproductive sectors and activities. ${ }^{9}$

9 In terms of policy, Sapsford and Balasubramanyam (2003) critique the IMF and World Bank structural reform agenda which advised African nations to increase their exports of (non-processed) primary products. They argue that this advice is subject to the fallacy of composition that a partial 
Another factor exacerbating the forces of uneven development at the global, regional and local levels is differential levels of social capital. Development scholars and sociologists have been concerned with social capital as a specific concept since the late I970s and I980s. Right up until the I990s, however, most political economists tended to evade the concept, because it was variously thought to be an incorrect view of scapital; or because it was a term better linked to notions of trust, sociality, networks, culture, reciprocity (and hence was thought to be superficially conceptualised); or because it meant different things to different people (Fine 200I). While many political economists ignored the term and/or the processes associated with it, the concept grew in importance, even affecting the more pluralistic elements of orthodoxy, and into the 2000 s most heterodox journals treat it with respect and concern. ${ }^{\text {Io }}$ It can also be used in a multitude of political and ideological ways, and has been propagated by the World Bank as well as the main development journals such as World Development and Journal of Human Development, not to mentioned hundreds of other media and interests.

Social capital typically includes those durable structures of trust and sociality helping to establish networks of relationships and associations within the community and which provide considerable public good functions of communication, information, and coordination. The socially broader the scope and spread of trust and sociality the greater the externalities and public goods associated with them, while the narrower the spread the more intense the vested interests are that appropriate benefits for themselves. For instance, the creation of truly social trust at the system level enhances virtually everyone's social objectives, including income, well-being and quality of life. The spread of trust within particular corporations, government departments or families will enhance the organisation of these specific sites of micro-practices. Promoting trust within groups of classes of people, such as among the upper classes, or within the middle class, with spread benefits within these particular groups, leads Pierre Bourdieu (1997) to argue that the asymmetrical distribution of social capital is the main factor propelling class distinctions.

This leads Paul Streeton (2002) to argue that social capital can simultaneously be both a stock and a flow in the sense that using it can reproduce it, in a circular and cumulative process. In like measure, the very process of people not trusting each other has the same circular and cumulative impact, but in a downward direction. But, says Streeton, there is also "asocial capital", in the sense that organised groups can use their own very specific internal social capital to destroy more general linkages of trust and sociality in the community. These special interest groups can take the form of terrorist cells (including government militia) that want to promote social fear and intimidation; an ensemble of

equilibrium solution for some nations is consistent with a general equilibrium solution for all such nations. Clearly, if all African nations export more primary goods, their terms of trade are likely to get worse.

IO For instance, a number of heterodox political economy journals have started publishing important articles on social capital, including, for instance, the Review of Radical Political Economics, the Review of Social Economy and the Journal of Economic Issues. 
corporations that want consumers to buy their products rather than enjoy free social (or public) goods; organisations such as the Ku Klux Klan that want to destroy trust within the black community and between blacks and whites; close-knit families that prevent their members from developing outside networks and associations; and growing markets that promote anonymous linkages between people and gradually reduce non-market networks and organisations.

In the current environment, for instance, globalisation has stimulated mainly corporate and market linkages, while the free movement of people for social ends has been limited. Consequently,

"the growth of institutions to protect the poor and the weak, to promote civil and human rights, to provide educational and health facilities and social safety nets, has lagged behind the drive to market forces. The result has been growing international inequality« (Streeton 2002: 18).

Hence the need to promote global relations of reciprocity, redistribution and embedded human markets rather than purely corporate and traditional market forms. There has been a major global decline in the percent of people who say that others are trustworthy over the past twenty years (O'Hara 2006b: ch. 3). This is likely the result of a shift from community and familial to market and corporate practices, as neoliberal economies (especially) have experienced a marked deterioration in trust over recent decades.

Declining trust increases the costs of legality, courts, jails and insurance; lowers the quality and level of information as well as public goods while it enhances individualism; and expands the asymmetry of information between groups. Most of these factors increase uncertainty, since there is less useful information to draw on about likely future tendencies and processes. Instability and insecurity increases, people feel more isolated, and are less willing to invest in the future. Being less willing to engage with people limits business expansion and networks of friends. For instance, a critical problem in many nations of Africa, Latin America and Asia is corruption, which represents a lack of truly social capital, since corruptors often look after family and friends at the expanse of strangers. The development of what Francis Fukuyama (2002) calls a »two-tiered moral structure « between insiders and strangers - or the problem of familism - is a normal response to a society where "people« are not trusting or are untrustworthy.

Heterodox economists have always recognised the importance of trust and sociality. Veblen was the first major economist to include it in his analysis through his concept of collective social wealth. Marx recognised the centrality of coordination and interaction through the circuit of social capital (for propelling surplus value) and wanted to promote trust within corporations and other institutions through major adjustments to social relations (his "association of direct producers«; see Prychitko I99I). Social economists have centred precisely on the role of trust, ethics and dignity in business and society. Feminists have long argued for an extension of caring practices that enhance trust, emotional bonding and love beyond the family. Post-Keynesians have for ages emphasised the need for incomes policies to improve trust between social classes, moderate distributional con- 
flict and improve performance. Radical political economists have recognised the need for numerous accords (and participatory democracy) between classes and groups to promote stability and conflict resolution. Rather than eschewing social capital because it is not a proper notion of capital as linked to business, heterodoxy needs to embrace it as a critical process of the political economy. Gradually it is becoming part of the heterodox mainstream. It provides an opportunity for different schools of heterodoxy to communicate with each other (promoting their social capital). Along with other processes, such as those linked to the Prebisch-Singer hypothesis, it enables us to gain an understanding of the forces of uneven development at the global, regional and local levels.

\section{Conclusion}

This paper commenced with the recognition of the need for both differences/specialization and interconnection/cross-fertilization within and between the schools of heterodoxy. Differences can stimulate conceptualization through specialization. Since the r960s, especially, this process of theoretical development has been stimulated by the focus on separate schools of political economy. Major improvements have been made concerning class and the economic surplus; effective demand and uncertainty; institutions, habits and instincts; innovations and technological change; the uneven forces of global capitalism; gender, class and ethnicity; plus strong sustainability and the precautionary principle. Without differences these developments would have been unlikely.

Even while the separate schools were active enhancing their concepts and perspectives, linkages started to emerge between them, and these linkages became greater as the degree of sophistication of the separate schools increased. An array of scholars have crossed school boundaries and started fusing concepts of other schools with their own (both wittingly and unwittingly). This led to a whole series of new research programs and conceptual innovations. Insights from many multiple schools were found to be complementary and enabled general concepts to be formed and enhanced. From this emerged, for instance, the notions of contradiction, heterogeneous agents and uneven development. At conferences, in journals and in departments the degree of cross-fertilisation between schools accelerates.

Ever while these cross-school communications continue the separate schools forge ahead with further technical and general advances. Some input into the schools is coming from the convergence process, while some of the further advances in the schools are affecting convergence trends. Both differences and linkages are needed for the further progress of heterodox political economy. May a hundred flowers bloom in both directions, greater depth and further widening of perspectives and concepts. We need both for healthy theory and policy, so that we are able to more fully understand the complexities of modern capitalism and the potential for social and political change into the future. May this process of reviewing the differences and commonalities within and between the 
schools continue in this journal and elsewhere. The future of heterodoxy depends upon such developments.

\section{References}

Arestis, Philip/Sawyer, Malcolm (eds.) (2000): A Biographical Dictionary of Dissenting Economists, Cheltenham, UK/Northampton, US: Edward Elgar

Arthur, Brian W. (1994): Increasing Returns and Path Dependency in the Economy, Ann Arbor: University of Michigan Press

Bankston, Carl/Zhou, Min (2002): Being Well vs. Doing Well: Self-Esteem and School Performance among Immigrant and Nonimmigrant Racial and Ethnic Groups, in: International Migration Review, Vol. 36, No. 2, pp. 389-415

Bourdieu, Pierre (1997): The Three Forms of Capital, in: Halsey, A.H./ Lauder, Hugh/ Brown, Phillip/ Wells, Amy Stuart (eds.), Education: Culture, Economy and Society, Oxford: Oxford University Press, pp. 46-58

Bowles, Samuel/Gintis, Herbert (2002): Social Capital and Community Governance, in: Economic Journal, Vol. II2, No. 483, pp. F419-F436

Brown, Doug (2002): Insatiable is Not Rational, Westport, CT: Praeger Press

Clark, Norman/Juma, Calestous (1987): Long-Run Economics: An Evolutionary Approach to Economic Growth, London: Pinter Publishers

Costanza, Robert (ed.) (1991): Ecological Economics: The Science and Management of Sustainability, New York: Columbia University Press

Cuddington, John/Ludema, Rodney/Jayasuriya, Shamila (2002): Prebisch-Singer Redux, Working Paper of the Economics Department of Georgetown University, January

Daly, Herman /Cobb, John B. (1989): For the Common Good: Redirecting the Economy Toward Community, the Environment and a Sustainable Future, Boston: Beacon Press (second edition)

Darity, William / Dietrich, Jason/Guilkey, David K. (200I): Persistent Advantage or Disadvantage: Evidence in Support of the Intergenerational Drag Hypothesis, in: American Journal of Economics and Sociology, Vol. 6o, No. 2, pp. 435-470

Dicken, Peter (2003): Global Shift: Reshaping the Global Economic Map in the $2 \mathrm{I}^{\text {st }}$ Century, London: Sage Publications

Drentea, Patricia/Goldner, Melinder (2006): Caregiving Outside of the Home: The Effects of Race on Depression, in: Ethnicity and Health, Vol. iI, No. I, pp. 4I-57

Fine, Ben (200I): Social Capital versus Social Theory: Political Economy and Social Science at the Turn of the Millennium, New York: Routledge

Freeman, Chris/Louca, Francisco (2002): As Time Goes By: From the Industrial Revolution to the Information Revolution, Oxford: Oxford University Press

Fukuyama, Francis (2002): Social Capital and Development: The Coming Agenda, in: SAIS Review, Vol. 22, No. I, pp. 23-37

Georgescu-Roegen, Nicholas (1971): The Entropy Law and the Economic Process, Cambridge, Mass.: Harvard University Press 
Ghosh, B. N. /Guven, Halil M. (eds.) (2006): Globalization and the Third World: A Study of Negative Consequences, Houndmills / Hampshire: Palgrave

Hewitson, Gillian J. (1999): Feminist Economics, Cheltenham, UK/Northampton, US: Edward Elgar

Hodgson, Geoffrey M. (2004): The Evolution of Institutional Economics, London/ New York: Routledge

Intervention. Journal of Economics [IJE] (2006): Aim and Scope, in: Intervention. Journal of Economics, Vol. 3, No. I, inside back cover

Jacobsen, Joyce P. (1994): The Economics of Gender, Cambridge, UK: Blackwell

Jaquette, Jane S. / Summerhill, Gale (2006): Women and Gender Equity in Development Theory and Practice, Durham: Duke University Press

Keohane, Robert O. (1984): After Hegemony: Cooperation and Discord in the World Political Economy, Princeton NJ: Princeton University Press

King, John (2002): A History of Post Keynesian Economics Since 1936, Cheltenham, UK/ Northampton, US: Edward Elgar

Lareau, Annette (2002): Invisible Inequality: Social Class and Childrearing in Black Families and White Families, in: American Sociological Review, Vol. 67, No. 5, pp. 747-776

Lavoie, Marc (1992): Foundations of Post-Keynesian Economic Analysis, Aldershot, UK/ Brookfield: Edward Elgar

Lavoie, Marc (2006): Do Heterodox Theories Have Anything in Common? A Post Keynesian Point of View, in: Intervention. Journal of Economics, Vol. 3, No. I, pp. 87-II2

Levine, David I./ Mazumber, Bhashkar (2002): Choosing the Right Parents: Changes in the Intergenerational Transmission of Inequality - Between I980s and the Early I990s, Working Paper of the Federal Reserve Bank of Chicago, No. 08

Lutz, Matthias, G. (1999): Commodity Terms of Trade and Individual Countries' Net Barter Terms of Trade: Is There an Empirical Relationship, in: Journal of International Development, Vol. II, No. 6, pp. 859-870

MacDonald, Martha/ Phipps, Shelley/Lethbridge, Lynn (2005): Taking its Toll: The Influence of Paid and Unpaid Work on Women's Well-Being, in: Feminist Economics, Vol. II, No. I, pp. 63-94

Milios, John/Dimoulis, Dimitri/Economakis, George (2002): Karl Marx and the Classics: An Essay on Value, Crises and the Capitalist Mode of Production, Aldershot, UK: Ashgate

O’Hara, Phillip Anthony (2000): Marx, Veblen and Contemporary Institutional Political Economy: Principles and Unstable Dynamics of Capitalism, Cheltenham, UK/Northampton, US: Edward Elgar

O'Hara, Phillip Anthony (200I): Contradiction, in: O'Hara, Phillip A. (ed.), Encyclopedia of Political Economy, London/ New York: Routledge, pp. I4O-I43 (paper edition)

O'Hara, Phillip Anthony (2003): The Revival of Political Economy and its Main Protagonists: I96os to the Present, in: History of Economics Review, No. 37, pp. I40-I5I 
O’Hara, Phillip Anthony (2006a): The Contradictory Dynamics of Globalization, in: Ghosh, B.N./Guven, Halil M. (eds.), Globalization and the Third World: A Study of Negative Consequences, Houndmills / Hampshire: Palgrave, pp. 17-35

O'Hara, Phillip Anthony (2006b): Growth and Development in the Global Political Economy: Social Structures of Accumulation and Modes of Regulation, London / New York: Routledge/ Taylor \& Francis

O’Hara, Phillip Anthony (2007a): Principles of Institutional-Evolutionary Political Economy: Converging Themes from the Schools of Heterodoxy, in: Journal of Economic Issues, Vol. 4I, No. I, pp. I-42

O'Hara, Phillip Anthony (2007b): Principles of Political Economy: Major Concepts and Applications to the Contemporary World, forthcoming

Ocampo, Jose Antonio/Parra, Maria Angela (2004): The Commodity Terms of Trade and their Strategic Implications for Development, Working Paper of the Economic Commission for Latin America and the Caribbean (ECLA), June

Polanyi, Karl (1944): The Great Transformation, Boston: Beacon Press, 1957

Prychitko, David L. (I99I): Marxism and Workers' Self-Management. New York: Greenwood Press

Resnick, Stephen / Wolff, Richard (1987): Knowledge and Class: A Marxian Critique of Political Economy, Chicago: University of Chicago Press

Resnick, Stephen / Wolff, Richard (2005): The Point and Purpose of Marx's Notion of Class, in: Rethinking Marxism, Vol. I7, No. I, pp. 33-37

Review of Political Economy [RoPE] (2006): Editorial Policy, in: Review of Political Economy, Vol. I8, No. 2, inside front cover

Review of Radical Political Economics [RRPE] (2006): Editorial Policy, in: Review of Radical Political Economics, Vol. 38, No. 2, inside front cover

Sapsford, David / Balasubramanyam, V. N. (2003): Globalization and the Glass Ceiling Hypothesis, in: Bloch, Harry (ed.), Growth and Development in the Global Economy, Northampton, US /Aldershot, UK: Edward Elgar, pp. 157-I69

Sen, Amartya (1999): Development as Freedom, New York: Anchor Books

Sherman, Howard J. (1987): Foundations of Radical Political Economy, Armonk/ New York:

M.E. Sharpe

Sherman, Howard J. (1995): Reinventing Marxism, Baltimore: John Hopkins University Press

Stanfield, James R. (1986): The Economic Thought of Karl Polanyi: Lives and Livelihood, New York: St. Martin's Press

Stanfield, James R. (1995): Economics, Power and Culture: Essays in the Development of Radical Institutionalism, New York: St. Martin's Press

Stockhammer, Engelbert (2004): Financialisation and the Slowdown of Accumulation, in: Cambridge Journal of Economics, Vol. 28, No. 5, pp. 719-74I

Streeton, Paul (2002): Reflections on Social and Antisocial Capital, in: Journal of Human Development, Vol. 3, No. I, pp. 7-22

Tool, Marc (200I): The Discretionary Economy: A Normative Theory of Political Economy, New Brunswick, US/London, UK: Transaction Publishers 
Veblen, Thorstein Bunde (I899): The Theory of the Leisure Class, Harmondsworth: Penguin, 1994

Vickers, Douglas (1995): The Tyranny of the Market: A Critique of Theoretical Foundations, Ann Arbor: University of Michigan Press

Whalen, Charles J. (ed.) (I996): Political Economy for the $2 \mathrm{I}^{\text {st }}$ Century: Contemporary Views on the Trend of Economics, Armonk/ New York: M.E. Sharpe 